\title{
Sim, elas envelhecem: problematizando a interseccionalidade entre gênero, sexualidade e idade
}

Travestis envelhecem?

ANTUNES, Pedro Paulo Sammarco.

São Paulo: Annablume, 2013. 258 p.

Atualmente, o cenário da pesquisa acadêmica no Brasil, principalmente em nível de pósgraduação (Mestrado e Doutorado), apresentanos um panorama indicativo de uma suposta escassez de produções que privilegiam a intersecção entre travestilidades e envelhecimentos. Em uma busca realizada preliminarmente na Biblioteca Digital de Dissertações e Teses (BDTD) base mantida pelo Instituto Brasileiro de Informação em Ciência e Tecnologia (IBICT), que integra os sistemas de informação de teses e dissertações existentes nas instituições de ensino e pesquisa brasileiras e estimula o registro e a publicação de teses e dissertações em meio eletrônico -, foram localizados apenas quatro trabalhos. Entre eles, uma tese (Siqueira, 2009) e três dissertações (Siqueira (2004), Antunes (2010) e Novas (2011)). Além disso, constatamos também que os trabalhos encontrados em rede são situados em três áreas de estudos - Antropologia, Gerontologia, Serviço Social - e orientados teóricometodologicamente sob uma perspectiva da Etnografia das Lacunas, com forte influência das Narrativas de Memórias Biográficas e as Trajetórias Sociais, destacando as Formas de Sociabilidade, os Itinerários Urbanos. Vale destacar que em ambos os trabalhos o caráter interdisciplinar é sempre evocado.

Tendo em vista essas considerações iniciais, podemos ressaltar que adentramos a um universo pouco explorado e pouco (re)conhecido. Sobre esse assunto recorremos ao psicólogo Pedro Paulo Sammarco Antunes, que, em seu livro denominado Travestis envelhecem?, convida-nos a uma leitura sobre as experimentações do desejo na trama do envelhecimento. $O$ trabalho do pesquisador é resultado de sua dissertação, produzida no Mestrado em Gerontologia pela Pontifícia Universidade Católica (PUC) de São Paulo e defendida em 2010. A obra de Pedro Antunes nos inquieta e nos faz pensar a relação entre gênero e idade na experiência política e cultural das travestilidades, a partir das narrativas de três senhoras. A construção da pesquisa reflete um percurso investigativo feito de caminhos/histórias de vida de travestis vivendo em contextos urbanos.

Na composição do livro somos inicialmente conduzidas/os a uma experimentação conceitual. Intitulado "Corpos, Controle e Resistência", o primeiro capítulo oferece a costura de conceitos foucaultianos, como saber, poder, disciplina, biopoder, controle e resistência. Esse arranjo exibe o esforço do pesquisador em romper com as fronteiras disciplinares e, além disso, visualiza o campo através de uma mirada interdisciplinar, aspecto relevante em sua tentativa em encorpar e incorporar seu objeto de estudo. Pedro Antunes, no capítulo 1 , analisa de forma histórica a constituição da heteronormatividade, contestando e colocando sob suspeita as noções bastante naturalizadas em relação à temática "corpo e velhice".

Apropriando-se da Filosofia e das Ciências Sociais para potencializar suas problematizações sobre as subjetividades na trama do envelhecimento, ele busca incessantemente argumentos para compor sua análise sobre uma interseccionalidade ainda timidamente trabalhada: gênero, sexualidade e velhice.

Travestis envelhecem? aponta para a estigmatização que marca o envelhecimento nas margens da heteronormatividade. Nesse sentido, a pesquisa desafia os jogos de verdade sobre as formas de saber que se entrelaçam à própria definição de um objeto a ser investigado: o amálgama corpo-gênero-sexualidade-idade na experiência da travestilidade. Cabe salientar que as noções de desvio e disciplina também fazem parte da (des)construção empreendida pelo autor.

No segundo capítulo, denominado "Corpo, Gênero sexual e Velhice", o pesquisador apresenta uma análise sobre a fabricação do corpo, realizando, a partir da experiência de suas interlocutoras, um demorado e minucioso trabalho. Para isso, Pedro Antunes parte da ideia de corpo como cenário de representações e símbolos culturais que assumem contorno singular de acordo com o lugar e época. A (auto)inteligibilidade 
é constituída, segundo o autor, por um longo percurso de fabricação que atravessa gerações. Cabe dizer que, nesse momento do livro, o autor se debruça a compreender os percursos de modificações corporais de suas interlocutoras, iniciadas desde jovens/adolescentes.

No que diz respeito às modificações corporais, Pedro Antunes reflete sobre a evidência das relações intergeracionais, considerando que a feitura dos corpos jovens geralmente se dá por travestis mais velhas. Algumas destas sendo, muitas vezes, denominadas por mãe ou madrinha pelas mais jovens. O pesquisador demonstra que certa transmissão cultural é feita intergeracionalmente. Emerge, por exemplo, a figura das mães, ligadas ao processo de transformação e de inserção das jovens a uma cultura específica: a cultura travesti. Observa Antunes que muitas mães consideram fabricar um corpo como fabricar, também, uma pessoa. Podemos ressaltar que, no arremate do capítulo 2, ele alinhou discussões sobre corpo, gênero sexual e envelhecimento, acionando pressupostos teóricos situados no campo das problematizações queer. É nesse momento que o conceito de performatividade toma fôlego, como elemento central para pensa a intersecção entre gênero e idade.

O terceiro capítulo é dedicado ao trabalho teórico-metodológico empreendido na pesquisa. Antunes destaca a relevância social do tema, chamando atenção para a necessidade de uma metodologia mais aberta aos jogos de significações culturais. Assim, a pesquisa biográfica envolve o encontro de narrativas e documentos sobre as histórias de vida de suas interlocutoras. A partir das experiências vividas pelas três senhoras, o autor vincula o pessoal com o social na articulação entre passado e presente. Sobre as interlocutoras, faz-se necessário informar que duas delas apresentam idade superior a sessenta anos, e uma terceira com mais de quarenta anos. O pesquisador justifica a inclusão da terceira interlocutora (com uma pessoa de quarenta e poucos anos) por perceber que o critério cronológico não contemplaria o que se propunha analisar. Ressalta ainda que a velhice no contexto travesti chega mais cedo, ponderando sobre as trajetórias de vida marcadas por contextos de violência de todas as ordens.

Temos, assim, um encontro com vozes e corpos marginalizados e silenciados. $O$ método biográfico ocupa, no terceiro capítulo, um lugar especial, não somente de rememoração, mas de atualização da experiência de si. Os resultados disso são colocados, em certa medida, como uma evocação de reflexividade para as mais jovens.

Por fim, o quarto capítulo apresenta a transcrição na íntegra das entrevistas. Apresentadas em seções para cada uma das entrevistadas, o autor justifica as transcrições fidedignas por acreditar que essa metodologia pode facilitar a outros pesquisadores que queiram utilizá-las eticamente, conforme seus respectivos objetivos de pesquisa. Além disso, as entrevistas transcritas dessa forma podem colaborar na identificação e definição de políticas públicas. Em relação à construção das entrevistas, importa acentuar que o conjunto delas é produzido em um jogo de perguntas e respostas, seguidas por alguns comentários do autor. A composição de Pedro Antunes revela um jogo aberto e franco, cujo percurso investigativo foi se definindo na experiência do contato entre pesquisador e interlocutoras.

Os achados do pesquisador se misturam ao seu encantamento com as interlocutoras. Para ele, as travestis mais velhas são exemplos, chegando à conclusão de que são consideradas modelos para as mais jovens. Podemos ainda ressaltar que a obra exibe narrativas um tanto nilistas, associando velhice e decadência, considerando-se, especialmente, a importância atribuída à beleza juvenil.

Travestis envelhecem? é uma entrada produtiva para as problematizações sobre envelhecimento, gênero e sexualidade. Seu universo de interlocutoras pode até ser 'pequeno', mas a intensidade de suas narrativas nos permite desviar o olhar e perceber a velhice como um lugar não apenas de tutela ou como um problema social, mas algo para pensarmos o que estamos tentando fazer de nós mesmas/mesmos diante dos códigos morais que encorpam os regimes discursivos em torno do humano viável e possível de nosso tempo e lugar no(s) (per)curso(s) da (re)invenção da vida. ' Certamente uma leitura problematizadora e emocionante.

\section{Nota}

' Fernando Altair POCAHY, 2011.

\section{Referências}

Travestis Envelhecem? 2010. 134 f. Dissertação (Mestrado em Gerontologia) - Pontifícia Universidade Católica - PUC, São Paulo, SP, Brasil, 2010.

NOVAS, Kleber de Mascarenhas. Travestilidades: trajetórias de vidas, lutas e resistências de travestis como construção de sociabilidade. Dissertação (Mestrado em Serviço Social) - Pontifícia Universidade Católica - PUC, São Paulo, SP, Brasil, 2011. 
SIQUEIRA, Mônica Soares. Sou Senhora: um estudo antropológico sobre travestis na velhice. 2004. 78 f. Dissertação (Mestrado em Antropologia Social) - Universidade Federal de Santa Catarina - UFSC, Florianópolis, SC, Brasil, 2004.

Arrasando Horrores! Uma etnografia das memórias, formas de sociabilidade e itinerários urbanos de Travestis das Antigas. 2009. $265 \mathrm{f}$. Tese (Doutorado em Antropologia Social), Universidade Federal de Santa Catarina - UFSC, Florianópolis, SC, Brasil, 2009.
POCAHY, Fernando Altair. Entre vapores e dublagens: dissidências homo/eróticas nas tramas do envelhecimento. Tese (Doutorado em Educação) - Faculdade de Educação, Universidade Federal do Rio Grande do Sul (UFRGS), 2011.

Francisco Francinete Leite Junior Universidade de Fortaleza

Fernando Altair Pocahy Universidade do Estado do Rio de Janeiro 